\title{
Attachment to God in Islamic Spirituality
}

\section{Bagher Ghobary Bonab, Special Education, PhD}

Associate Professor, University of Tehran,

School of Psychology \& Education, Ale Ahmad Ave, Under Geesha Bridge,

P.O. Box 14155-6456, Tehran, Iran

Email: b.ghobary@uws.edu.au

Maureen Miner, B.Sc. (Hons), M. Clin. Psych. PhD

Senior Lecturer, School of Psychology, University of Western Sydney, Locked Bag 1797, Penrith South DC NSW 1797 Australia

Principal Research Fellow, Australian Centre for Studies in Spirituality

PO Box 224, Roselands, NSW, 2196, Australia

\author{
Marie-Therese Proctor, B.A. (Psychology Hons), PhD \\ Psychologist/Research Officer: Life Limiting Conditions Project, \\ Oncology Dept, \\ The Children's Hospital at Westmead, \\ Locked Bag 4001, Westmead, NSW 2145 Australia
}

\section{Abstract}

The aim of this investigation was to explore the quality of attachment to the divine in Islamic spirituality. Theories of attachment to God have been developed with respect to the Christian faith, but it is important to explore whether Allah functions as an attachment figure in Islamic theology. Specifically, the paper considers whether believers generally seek proximity to Allah as a safe haven in times of distress; use Allah as a secure base for living in the world; and view their relationship with Allah in terms of dependency, closeness, and alleviation of anxiety. To this end, five types of Islamic texts were reviewed: a) the beautiful names of Allah (divine attributes) for any attributes that signify Allah as a caring, nourishing, and omnipresent attachment figure; b) stories of the Qur'an that signify dynamic attachment relations between Allah, His prophets, and servants; c) verses of the 
Qur'an that emphasize the caring and supportive relationship between Allah and His servants; d) divine sayings and prophetic inspirations that underscore Allah as a caring and supportive attachment figure; and e) suggested supplications which reveal individuals' deep and dynamic relations with Allah. The possibility of insecure attachment to Allah was also examined. The results of this theoretical study indicated that Allah functions as an attachment figure for believers, and most believers' rituals and behaviors are based on proximity-seeking to Allah. Implications of the current review for the conceptualization of attachment to Allah in Islamic spirituality and for scale development of relevance to Muslims' mental health are discussed.

Keywords: attachment to Allah, Islamic spirituality, secure base, safe haven, proximity-seeking behavior, Qur'anic stories, Islamic supplications.

\section{Introduction}

Within the psychology of religion, attention has been directed to attachment to God as an important new field for investigating individual differences in spirituality (Hill, 2005). Attachment theory is claimed to be a powerful integrative framework that contributes to the understanding of spiritual phenomena (such as conversion and prayer), the consequences of spirituality (such as interpersonal relationships and coping; Kirkpatrick, 1992a, 2005), and greater mental health (See Granqvist \& Kirkpatrick, 2008 for a review). Whereas attachment to God has been studied with respect to Christians' relationship experiences, some authorities (e.g., Glaser, 1986) question the applicability of attachment theory to Islamic spirituality. Thus it is important to examine the relevance of the attachment construct for Muslims if it is to contribute to greater understanding of Muslim spirituality and mental health.

Islamic spirituality is defined as the presence of a relationship with Allah that affects the individual's self-worth, sense of meaning, and connectedness with others and nature (Nasr, 1997). The relational quality of spirituality is understood to be a core theme of Islamic religion that comprises beliefs, rituals, daily-living behaviors, and knowledge. Hence, central beliefs of the Islamic religion -- such as belief in Allah and His prophets, judgment day, etc. -- are lived out daily in spirituality, ways of relating to Allah, others, nature, and the self. Similarly, in following the set of rituals and codes of Islamic religion, an individual is striving to become closer to Allah and to find personal worth and actualization (Khodayari-Fard et al., 2008). Hence, spirituality is depicted as the individual, motivational, and relational 'face' of religion.

Since relation to Allah is a central theme in Islamic spirituality and Islamic religion, in the context of attachment to Allah, Islamic spirituality and religion point to the same construct. However, the term "Islamic spirituality" is pre- 
ferred in the context of attachment theory because it emphasises the core of Islam and highlights the psychological reality of religion for Muslims.

\section{Attachment Theory}

As postulated by John Bowlby $(1969 ; 1973 ; 1980,1982)$, attachment is a biologically based behavioral system designed to promote the seeking of proximity to a protective other, or attachment figure, at times of environmental threat. An adequate attachment figure is sensitive and responsive to the individual's proximity-seeking behaviors (Ainsworth, Blehar, Waters, \& Wall., 1978; Bowlby, 1982; Hazan \& Zeifman,1994). Emotions and behaviors consistent with anxiety, including protest at separation from the attachment figure, are expected to persist until the set goal of proximity has been attained (Hazan \& Shaver, 1994). Not only is the attachment system activated in infancy but it also operates throughout the lifespan (Mikulincer, Gillath, \& Shaver, 2002).

The attachment figure plays a pivotal role in the attachment relationship. This role is best characterized as a combination of accessibility, as marked by actual or potential presence, and a willingness to respond in an appropriate way, for example, as comforter or protector (Bowlby, 1973, 1987; Hood, Spilka, Hunsberger, \& Gorsuch,1996; Feeney, 2007). Descriptors such as accessible, available, responsive, loving, caring, and comforting feature among terms used to characterize an optimal human attachment figure, whose function primarily is to provide physical protection in childhood and psychological care, comfort, support, and assistance throughout the lifespan (Bowlby 1973, 1988a, 1988b). Such descriptors imply the potentiality for one to connect with an attachment figure in a highly personal and relational manner, via a bond that is predominately experienced as affective (Sroufe \& Waters, 1977; Sroufe et al.,1999; Jaffari-Bimmel et al., 2006).

In times of stress or danger, a child attempts to elicit protection from the attachment figure by engaging in proximity-seeking behaviors, including crying and other protest at the separation. If the attachment figure provides protection, comfort, and support, the child experiences 'felt security' and a 'secure home base' from which to engage in psychological and physical exploration (Bowlby, 1982, 1988c). Thus the relationship between an individual and an attachment figure is marked not only by proximity-seeking and separation anxiety, but also by the provision and use of the safe haven and secure base functions of the attachment bond (Ainsworth, 1985a). Secure attachment, where the caregiver adequately fulfills attachment functions and the child experiences felt security, theoretically promotes optimum personality development and psychological functioning of the child (Bowlby, 1988c). On the other hand, if the child does not experience protection, comfort, and support from a caregiver, the child may develop an insecure attachment relationship. Such an insecure attach- 
ment relationship is marked by disturbed proximity-seeking (e.g., ambivalence or avoidance), absent or prolonged separation anxiety, and distortions of the secure base function (e.g., clinging or self-absorption; Ainsworth, 1985b). In total, three different styles of insecure attachment have been identified: preoccupied (ambivalent and clinging), avoidant (dismissing of the other), and fearful (both anxious and avoidant; Bartholomew \& Horowitz, 1991).

Research has shown that secure attachment bonds and positive schemas allow the person to maintain positive emotions while reducing the intensity of negative emotions (Schore, 2003), and hence allowing positive adjustment to stress. Insecure attachment schemas result in biased information processing, poor emotional regulation (Cassidy, 1994), and vulnerability to stress-related and personality disorders (Sroufe et al., 2005). Moreover, researchers have found an association between insecure attachment, delinquent and antisocial behavior (Allen et al., 2002), substance abuse (Hull, Young, \& Jouriles, 1986) and criminal actions (Doyle \& Markiewicz, 2005). These findings point to the importance of research into secure and insecure styles of attachment for understanding a range of mental health outcomes.

\section{Attachment to God}

In the context of the Christian experience, the metaphor of human attachment has been used to explain a foundational aspect of divine-human relationships. Thus, the Christian God is perceived to function psychologically in a manner consistent with the function of a human-attachment figure (Kirkpatrick, 1999, 2005; Proctor, 2006). Likewise, the Christian believer, much like the developing child, is the recipient of the psychological benefits of having a stronger protective other available in the event of threat. An analysis of Christian theology and empirical studies indeed supports these contentions (Kirkpatrick \& Shaver 1990, 1992; Kirkpatrick 1997, 1998, 1999, 2005; Miner 2007, Proctor 2006; Proctor, Miner, \& Dowson -in press).

Research has consistently shown that individuals with higher religious commitment have better mental health and coping ability (See Miller \& Thoresen, 1999 for summary). Enhanced coping and better mental health are generally related to having a positive personal relationship with God (Belavich \& Pargament, 2002; Pargament, 1997). From an attachment perspective, the benefits of a personal relationship with God stem from God functioning as a supportive attachment figure, acting as a safe haven wherein the individual is soothed and comforted during times of threat, and as the individual's secure base from which he/she explores and finds courage to engage with the challenges of life.

A number of studies since the 1970s have explored the association between relationship with God and mental health. For example, Galanter, Rabkin, Rab- 
kin and Deutsch (1979) reported that two best predictors of emotional wellbeing in his survey were "comfort that individuals obtained from relation with the divine being" and "feeling their close and intimate connection with the divine being." Pollner (1989) found that a dimension of religion labeled "divine relationship" (defined as psychological proximity to the divine, and depth of relationship with Him) predicted well-being more strongly than other religious variables (such as church attendance). Poloma and Gallup (1991) discovered that prayer and, particularly, experience of God during the prayer was strongly associated with several indicators of well-being. Kirkpatrick and Shaver (1992) reported individuals who were securely attached to God scored lower on psychological symptoms including loneliness, depression, anxiety, and physical illness. The securely attached were also substantially higher in general life satisfaction. Among more recent studies there are examples such as Kirkpatrick, Shillito, and Kellas (1998), who found that having a close relation with God was associated with reduced loneliness (Kirkpatrick et al. 1998). Likewise, turning to God as an omnipresent and omnipotent attachment figure has been associated with an improved sense of well-being (Granqvist \& Kirkpatrick, 2008), and reduced anxiety and depression (Ullman, 1982). In general, data has indicated that attachment security is linked with better coping abilities (Belavich \& Pargament, 2002; Pargament, 1997), well-being, positive mental health, and superior relationship functioning (Crowell, Fraley, \& Shaver, 1999; Dozier, Stovall-McClough, \& Albus, 2008; Hesse, 1999; Sable, 2000).

Conversely, insecure attachment to God has been found to be associated with negative mental health outcomes. For example, insecure attachment to God is related to negative affect (Rowatt \& Kirkpatrick, 2002), loneliness (Kirpatrick, Shillito, \& Kellas, 1998), anxiety and poorer existential well-being (Miner, 2009), and less helpful religious coping that predicts poor adjustment (Belavich \& Pargament, 2002). Several studies show that attachment to God is related to health outcomes beyond the effects of human attachment (e.g., Miner, 2009; Sim \& Low, 2003), thus highlighting the importance of assessing attachment to God, in addition to human attachment relationships, when mental health outcomes are of interest.

\section{Theoretical and Methodological Limitations}

One limitation of studies investigating spiritual attachment is their use of Christian samples only, and it is presently unclear if their findings generalize to other religious groups, such as Muslims. Hence, empirical studies with Muslim populations are required. However, to date, there has been neither an analysis of Islamic writings, nor empirical studies that have directly explored the viability of attachment theory as an interpretative framework for understanding a Muslim's relationship with Allah. Some theoretical writings have addressed 
the association between Islamic spirituality and psychological issues in ways that offer indirect support for the assumption that attachment to God may be a relevant construct for Muslims. In their development of an Islamic psychology of personality, Haque and Mohamed (2009) ground their work in the concept of fitrah, which is defined as the "innate and natural disposition of man to believe and worship God" (p. xxiv). As a further basis for relationship with God, they assert, "A relationship with the Creator can be established through ibadah (knowledge and actions)," and, "the key to knowledge of God is knowledge of one's self both inwardly and outwardly" (p. xxix). Earlier, Mohamed argued that fitrah, together with divine revelation, allows humans to attain "all levels of perception, even the knowledge of Allah in a direct and immediate way" (1998, p.97). Hence, Mohamed and Haque posit certain spiritual and psychological conditions that are conducive to relationship with God, considered in broad cognitive-behavioral terms. Other writers considering religiously appropriate therapy for Muslims discuss the religious shaping of personality (Dwairy, 2006), and sections of journals such as the Journal of Muslim Mental Health are devoted to the examination of faith-based mental health practice (e.g., Kobeisy, 2006). Such analyses of personality and cognitive change among Muslims provide some basis for understanding models of self in relation to God-models that are of central importance to issues of spiritual attachment and mental health.

In addition, there are a number of measures of religiosity and spirituality for use with Muslims. Such scales contribute to understanding of how individuals generally relate to Allah in Muslim societies. Some early measures were based on the Glock and Stark model of religiosity (e.g., Pouryousefi, 1984, and Samandari, 1982), while later researchers did not specify the underlying model of their assessment device (e.g., Serajzadeh, 1998). In these three cases, the scales' internal validity and reliability were not reported. Further, the Glock and Stark model assumes basic commonality between the monotheistic religions and ignores the uniqueness of Islam. Even the more recent and psychometrically robust scale of Muslim Attitudes Towards Religion (MARS) developed by Wilde and Joseph (1998) has items adapted from the Francis Attitude Towards Christianity Scale (Francis \& Stubbs, 1987). On the other hand, more recent tools, such as the Islamic Reflection Scale (IRS) developed by Dover, Miner, and Dowson (2007), are based on an understanding of Islamic principles rather than being derived from Christian measures, and provide a more culturally sensitive estimate of individuals' religiosity in Islamic societies. However, there is no measure of attachment to God (Allah) for Muslim people. Advances in both theory and measurement are required if attachment to God (ATG) is to be applied coherently to Muslim mental health. Theoretically, what is needed is to establish that: a) Allah is perceived as possessing qualities consistent with an attachment figure according to Islamic texts; and b) Muslims respond to Allah 
in ways that are consistent with secure and insecure attachment styles. Empirically, tools that can measure secure and insecure attachment to God are needed for research to investigate relationships between styles of ATG and Muslim mental health. Hence, it is critical to conduct an analysis of Islamic texts and Muslim spirituality in order to ascertain whether attachment theory applies to Muslims. Then, relevant measuring tools based on the established theory can be developed. Subsequently, the valid and reliable measuring tools can be applied to concerns such as the mental health of Muslims.

This paper focuses on the first step: the theoretical relevance of ATG for Muslims. It explores the theological basis of attachment to Allah as a necessary step within a larger project focused on developing an 'attachment to Allah' scale that is solidly grounded in Islamic spirituality. First, the paper considers relationship with Allah in Islamic spirituality, identifying the extent to which Allah is depicted as an attachment figure in Muslim sources. Then it presents depictions of Muslim believers' exhibiting behaviors consistent with having an attachment to Allah, i.e., proximity-seeking behaviors and displays of separation anxiety. It provides accounts of relationships between Muslims and Allah that are consistent with attachment theory. Finally, implications of attachment to God for Muslim mental health are presented.

\section{Relationship with Allah in Islamic Spirituality}

An individual's relationship with Allah is the focal point of Islamic spirituality. At the heart of human-divine relationship is divine love. Allah's love of humans is made clear in divine sayings such as the following:

God ever mighty and majestic says: "O child of Adam, it is your right from Me that I be a lover for you. So, by My right from you, be for Me a lover (Ibn Arabi, ${ }^{1} 2004$ edition, p. 24).

1. Ibn Arabi (1165-1240) was a famous Islamic scholar in 12th century who developed philosophy of Islamic mysticism. He has published widely in most of the Islamic sciences, covering the areas of human spiritual development, Qur'an interpretation and prophet's tradition. He has compiled "divine sayings" narrated by Prophet Mohammad. His famous book titled "The Meccan illumination" is an encyclopaedia of Islamic sciences in a Sufi tradition. Ibn Arabi was a very influential Muslim scholar who wrote over 350 works including the famous "Fusûs al-Hikam." According to the international Ibn Arabi society his influence extends beyond the development of Islam to western philosophy and literature. Although he writes from a mystical, Sufi, perspective, he is nonetheless acknowledged by other Muslims for his excellent commentary on the Quran. Ibn Arabi distinguishes and writes about tradition (sayings and actions of the Prophet), reason (philosophy-theosophy) and mystical insight. He considers parallels between human love and divine love (see his famous book of poetry, Tarjumân al-Ashwâq). 
Quranic stories and statements show that Allah was always with His prophets and His servants. In turn, the prophets sought always to serve Allah, the Prophet Mohammad (PBUH) saying:

Surely, my prayer and my devotion, my life, and my death are all for Allah, the Lord of the worlds. He has no partner, and this is what I have been commanded, and I am the first of the Muslims (6:162-163).

Mutual relationship between the Divine and human beings is thus regarded as an important Islamic value within Muslim spirituality. Evidence of this mutuality is articulated in the following prophetic saying:

God, ever mighty and majestic is He, says, "I am present in my servant's thought of Me, and I am with him when he remembers me." If he approaches Me by a hand's breath, I draw near to him by an arm's length, and if he draws near to Me by an arm's length, I draw to him by a fathom. If he comes to Me walking, I come to him running (Ibn Arabi, 2004 edition, p. 24).

Religious rituals are integral to Islamic spirituality as they provide a means to demonstrate and maintain relationship with Allah. Further, they are an outward expression of the believer's desire to maintain closeness to Allah, especially during times of psycho-spiritual or physical threat. In addition, relationship with others is considered part of relationship with the divine. Loving others, giving unconditional positive regard to others, and altruistic acts are examples of religious virtues that demonstrate an individual's deep and sincere relationship with Allah. The following hadith captures this point:

God, ever mighty and majestic is He, shall say on the day of resurrection: "Where are those who have loved each other for the sake of My Majesty?

Today I shall shelter them in My shade, on a day when there is no shade but My shade (Ibn Arabi, 2004 edition, p. 34).

\section{Understanding Allah in Transcendental and Immanent Manifestations}

An understanding of the relationship between individuals and the divine in Islamic spirituality requires distinguishing two complementary views of God's relationship with creatures, immanence, and transcendence. Most Islamic scholars (e.g., Ibn Arabi, 1980; Al-Ghazzali², 1992; Chittick, 1989, 1998) believe that God (Allah), in His essence, is the transcendental unity who is majestic and

2. Al Ghazzali (1055-1111) was one of the greatest Islamic Jurists, theologians, and mystical thinkers in 11th century. He has published nearly 400 books on a variety of subjects including 
beyond any human comprehension. However, He has an active relationship with creation at the level of immanence. In other words, Allah is immanently connected to the created order, so that divine life cannot be detached from the created order.

At the level of immanence, the created order (i.e., the cosmos, humanity, and each individual) is understood on the basis of Allah's beautiful names (divine attributes). Divine attributes are archetypal entities through which divine actions are organized and take place. In other words, Allah's relationship with His servants, functioning at the level of immanence, is based on divine attributes. Allah's ninety-nine beautiful names indicate that an intimate relationship exists between individuals and the divine being. In addition to these divine attributes (ninety-nine names), stories in the Qur'an and divine sayings (Ibn Arabi, 2004) support these intimate relations. Qur'anic verses, Quranic tales, or narrated sayings from His prophet (PBUH) thus must be read and considered within the context of this ongoing connection and unity.

Whereas from a theological perspective it has been argued above that Allah is immanently related to humans, the question is what kinds of relationships are perceived to exist between Allah and His servants? Based on analogies from human relationships and analysis of relational psychological systems (Kirkpatrick, 2005), God may be viewed in attachment terms (as caregiver, or as lover using the metaphor of romantic attachment), in terms of power (as king or ruler or coalition leader), in economic terms (as an agent in socioeconomic exchange), in social terms (as a prestigious figure) and perhaps in terms of guidance (as counselor, mentor, or source of wisdom). This paper specifically addresses the relational subset of the attachment system and asks: Is an aspect of the broader relationship able to be conceptualized as an attachment bond, wherein (i) Allah functions (in certain contexts) like an attachment figure, via the provision of protection, comfort, support and assistance in times of distress or threat; and (ii), the believer, in relationship with Allah, experiences the psycho-spiritual benefit of 'felt security' as a consequence of Allah's provision of protection following the believer's seeking of Allah as the 'stronger wiser Other' (Kirkpatrick, 1992b, 2005)?

In order for a relationship to be considered to entail an attachment component, it is important to demonstrate both caregiving qualities of the attachment figure and care-seeking behaviors that characterize the attachment behavioral system (Cassidy 1999). More specifically, is Allah perceived as an attachment figure by believers, wherein they call on Him for refuge in times of distress, trusting Allah to be their safe haven, their place of refuge? In the event that believers experience such refuge and come to understand the ongoing availability of Allah during difficult times, do they venture outward, exploring life, thereby demonstrating they experience and consider Allah to be their 'secure base'? Is philosophy, mysticism, Qur'anic sciences, and the prophet traditions. His famous book on "the ninety-nine beautiful names of God " describes God's attributes. 
there evidence that believers protest and lament felt separation from Allah and likewise exhibit proximity-seeking behaviors in the pursuit of greater closeness to Allah, especially in the context of distress and threat? Further, since individual differences have been found with respect to human attachment and attachment to God among Christians, such that patterns of insecure attachment marked by anxiety and avoidance have been found, is there evidence that some Muslims might experience Allah as an inconsistent or absent refuge, an unreliable secure base, or a power to be feared and avoided?

To address these questions multiple Islamic sources were examined to discern both qualities of Allah that parallel those of an attachment figure and for evidence of believers exhibiting attachment-related behaviors, both positive (indicating secure attachment) and those indicating insecure attachment. This analysis provides an evidentiary basis in support of the contention that an attachment bond can form and function within Muslims' relationship with Allah. It is not an exhaustive analysis and does not suggest that all Muslims find Allah to be a responsive attachment figure. However, it provides cumulative illustrations of religious figures who are considered to be role models for believers. The following sections demonstrate (1) how Allah is introduced to Muslims by divine attributes that include attachment-related themes; (2) how Qur'anic tales depict attributes of Allah as the ultimate attachment figure; (3) how direct revelations (verses) amplify divine sayings and stories in different chapters of the Qur'an demonstrate Allah's closeness, accessibility, availability, care, and protection on the one hand, and as punishing, just, and avenging in other circumstances. Further, believers' responses to Allah (as depicted in their supplications and their accounts of separation protest) were examined for attachment-related behaviors by believers. The treatment here cannot be exhaustive, but will indicate areas for further investigation by the interested reader.

\section{The Root Meaning of Attachment Qualities in Islamic Faith}

The premise for considering aspects of Muslim believers' relationships with Allah functioning as attachment bond can find its starting point in the Arabic word 'Iman' translated as 'faith' (Qur'an 2:108). Derivatives of the same word root convey the following meanings: safety (Qur'an 2:234), peace (Qur'an 4:91), security (Qur'an 7:97), certainty (Qur'an 2:260), and trustworthiness (Qur'an 26:107). Those who have faith experience security with Allah (Qur'an 6:82), and with believers who trust in Allah and His messenger (Qur'an 24:62). Pondering on the Arabic root of 'Iman' (faith) in Islamic theology reveals that "to be secure", trust, entrust, and the state of safety are included in the meaning of faith. Each of these terms supports the importance of Allah as an attachment figure providing security in Islamic theology. 


\section{Allah as an Attachment Figure}

The attachment bond as a relationship is dyadic in form. Exploring the contribution and role of each dyadic partner is crucial when seeking to substantiate that a relationship entails an attachment bond, where one partner functions as the "stronger wiser other" (Kirkpatrick, 1992a, 2005). The following section examines multiple sources of evidence that supports the notion Allah is considered as an attachment figure within Islamic spirituality.

\section{Allah as an Attachment Figure as Illustrated by Divine Attributes}

Qualities of an attachment figure conducive to the attainment of proximity and safety include accessibility, sensitivity, responsiveness, and the capacity to provide protection; the qualities related to provision of a secure base involve support of exploration and learning (Bowlby 1977; Ainsworth et al., 1978; Sroufe \& Waters, 1977; Pargament, 1997). Examination of Islamic writings reveals that among the divine names of Allah, there are divine attributes reflecting qualities of an ideal attachment figure.

According to Islamic belief, Allah can be understood via the ninety-nine (Al-Bukhari $\left.{ }^{3}, 1979\right)$ attributes or divine names of Allah. Each name has a specific effect in regulating divine relations with people. A review of the divine names reveals that some are especially salient with respect to attributes that characterize the functions of a attachment figure.

Key among the attachment salient divine attributes is Al-Mu'min-The Preserver and bestower of security. The provision of security lies at the heart of the attachment bond, wherein a threatened individual turns to a stronger other in search of safety. This divine name denotes Allah as the only one who provides security for individuals in the context of either external threats and/or inward temptations (Qur'an113: 1-5; 114: 1-6). Believers can seek and find refuge in Allah, assured it will be provided:

... You are the faithful who rests in security, and I am God the Faithful who bestows security ... There shall be no fear for you, nor shall you be sad, ... You are in My abode" (Ibn Arabi, 2004 edition)

3. Al-Bukhari (810-870) Muhammad Ibn Ismail Ibn Ibrahim Ibn al- mugirah Ibn Bardizban al-Bukhari popularly known as Al- Bukhari or Imam Bukhari was a famous Sunni Islamic scholar of Tajik ancestry. He was, perhaps, best known for authoring the hadith collection named Sahih Bukhari, a collection which Sunni Muslims regard as the most authentic of all hadith compilations and the most authoritative book after the Qur'an. 
Another key attribute of an attachment figure is his/her willingness to respond when protection is sought. The divine name Al-Mujib -The Responsive affirms to the Muslim believer that Allah is indeed available and willing to respond when His protection is required, Qur'anic stories revealing Allah's commitment to respond:

when my servants question you about Me, I am near to answer the call of the caller when they call Me (Quran 2:186).

Other divine names further speak to Allah functioning as an attachment figure. For example, implied in the name Ar-Razzaq-The Ever-provider is provision and fulfillment of creatures' needs including their nourishment, safety, comfort, and shielding. When believers need safety and security in various physical, social, psychological, or even spiritual domains, they can call out this archetypal name, and are granted what they need: "God is the one who gives sustenance, the possessor of strength, the firm" (Qur'an 51:58). The crucial role of the attachment figure as protector is also captured in the divine name $\mathrm{Al}$ Hafeez. Allah provides care and protection for individuals who believe in Him. The pervasiveness of this protective function is demonstrated in the stories of the prophets who determinately and courageous delivered Allah's messages, confident that $\mathrm{He}$ would protect them from harm and adversaries. Stories from the Qur'an give many examples of Allah protecting individuals from various adversaries. Allah saving Noah and his followers (Qur'an 7:64); protecting Moses and his people from the persecution of Pharaoh and his army (Qur'an 2:49); saving Moses from grievous consequences and protecting him from Pharaoh's plot to kill him when he was a child (Qur'an 20:40), are but a few of many examples that speak of the protection of Allah that believers can and do call upon when required. The notion of protection is further captured in the divine name Al-Manie- The Shielder. Herein, Allah deflects all sources of loss and danger threatening His servants, for He has all means of preventing harm to His creatures. Muslims evoke this name in order to be shielded from dangers and adversaries (see Al-Ghazzali, 1992 for further elaboration). Another example of a divine name is As-Samad-The Everlasting Refuge. Knowing that refuge will be reliably available is a crucial aspect of the safe haven function of attachment, since the individual comes to know his/her attachment figures are reliable. Clearly Allah as an everlasting refuge implies that a safe haven can be found in Allah. An example of this attachment function at work is evident in chapter 18 of the Qur'an. The "Companions of the Cave" describes the story of the Seven Sleepers who sought refuge in Allah from the tyrant king who was persecuting them. Allah guided them to a safe place and gave them refuge from the cruel and unjust king. In sum, this small selection of attachment-salient divine names and attributes provide a clear foundation from which to further 
explore when and in what ways Muslim believers can experience Allah as an attachment figure.

\section{Allah as an Attachment Figure in Qur'anic Stories}

In addition to showing divine attributes that are consistent with attachmentrelated attributes of an attachment figure, it is important to establish whether Allah is depicted as providing the attachment functions of proximity, safe haven, and secure base. Various stories of the Quran concerning Adam and other prophets including Idris, Noah, Hud, Salih, Abraham, Lot, Joseph, Job, Jonah, Moses, Zachariah, Ishmael, Jesus, and Muhammad illustrate Allah's availability, accessibility, responsiveness (to calls for help), care, and protection. For the sake of brevity just a portion of some of the stories that deal with attributes of Allah in this respect are mentioned, relating to Jonah, Abraham, and Moses.

\section{Allah as 'Safe Haven' and 'Secure Base' in Qur'anic Stories}

Key roles of an attachment figure include (i) provision of safety, wherein the attachment figure acts as a haven and a place of refuge when protection is sought during times of threat and (ii) a secure base from which the protected one can confidently explore, assured of a reliable response from the attachment figure should threat be re-experienced. The safe haven function, represented by the responsiveness of Allah as an attachment figure, and His availability for care and protection of Jonah are illustrated in chapter 21 of the Qur'an. The night journey of Jonah shows how believers can seek refuge in Allah and consider Him as an available source of comfort, rescue, and haven of safety in times of needs. In the face of threat and despair, Jonah called to Allah, thereby demonstrating his desire for greater proximity to, and protection from, Allah:

And Jonah departed in anger and thought that We had no power over him; he ended up imploring from the darkness (of the big fish's belly): There is no god other than You. Be You glorified. I have been one of the wrongdoers. So We responded to him and delivered him from his grief. Thus We deliver the believers (Quran. 21: 87-88).

The responsiveness of Allah to Jonah during a time of distress, Jonah's calling out to Allah for help, and his deliverance from his unfortunate situation are clearly illustrated in this story-all of which bear the hallmark characteristics of the safe haven function of attachment. Yet attachment is a relationship not confined to heroes and role models: it is written that recourse to Allah is not solely the reserve of nor limited to prophets, but can also be available to other believers (Qur'an 21: 87-88). 
The story of Abraham further illustrates the way in which Allah protects and can be a place of refuge for his believers/followers (Qur'an 19, 21, 26, and 29). For example, in chapter 21 (51-72), Abraham was faced with the threat of death for reasoning that idols are not worthy of worship, and that the Lord of the heaven and earth must be worshipped instead. Allah saved Abraham from those who planned to burn him, and hence Abraham testified to Allah's righteousness and His making of Abraham's enemies' plot ineffective:

They said, Burn him (Abraham) and help your gods, if you are going to act. We (Allah) said O' fire, be a coolness and peace for Abraham. They desired to plot against him but We made them the great losers" (Qur'an 21: 68-70).

Some commentaries suggest Abraham was so confident of Allah's help he refused help offered by angels saying that Allah was sufficient for him. Of this, Ibn-Kathir ${ }^{4}$ (2003), one of the famous Islamic historians writes:

When Abraham was placed on the catapult, shackled in chains and then thrown in the fire, he said: 'Allah is sufficient for us, and how good a protector He is!' . . It is narrated that when he was thrown and was still in the air, Gabriel approached him and said to him Abraham! Do you need any help? He replied: If from you, then no.

This story illustrates very clearly both (i) Allah was available and accessible when needed (functioning as an attachment figure) and (ii) the responsiveness of a believer who had faith in Allah, with Abraham declaring Allah to be his only source of care and protection. In this example can be seen both functions of attachment at play, that of Allah being both a safe haven as well as a source of security (the secure base function) for Abraham, with Abraham finding in Allah's protection and care the strength to carry out his mission.

Other Qur'anic stories depict the safe haven and secure base functioning of Allah. The stories of Noah (26: 105-122), Hud (26: 123-140), Salih (26: 141-159), Lot (26: 160-175), Shuayb (26: 176-191), and Prophet Muhammad (Qur'an 3: 173-174) bear further witness to Allah's provision of protection and security. They demonstrate how the prophets as well as believers can find in Allah comfort in His abode and a source of courage to deal with enemies effectively (secure base). An important and highly relevant example of this is seen in the final encounter between Pharaoh, tyrant king of Egypt, and Moses. Threatened by Pharaoh with death (Qur'an 7: 127), Moses gets direction from Allah:

4. Ibn-Kathir (1301-1373) was a Shafie scholar and Qur'an commentator who wrote a famous commentary on the Qur'an, and a masterpiece on the history of prophets. He was born in 1301 in Busra, Syria. 
We suggested to Moses: Travel by night with my servants for you will be followed. Pharaoh sent heralds to all the cities: These are only a small band and they have surely enraged us, but we are a host who are on our guard ... and they (Pharaoh's soldiers) followed them at sunrise. When two hosts saw each other, the companion of Moses said: We are surely overtaken. Moses said: By no means; my Lord is with me and He will guide me (Qur'an 26: 52-62).

In this distressing situation, Allah can be seen to be both Moses's safe haven and his secure base. When his companions expressed their worries about being overtaken, Moses was certain about the availability of his Lord and of having access to divine guidance. That Moses's faith in Allah is well placed is revealed in the remainder of the story wherein Allah guided him through the battle.

We suggested to Moses, strike the sea with your staff. It parted and each part was like a vast mountain. And We let the other party approach there. And We saved Moses and all those who were with him. Then We drowned the others. In that there is a sign ... Your Lord is mighty and compassionate (Qur'an 26: 62-68).

In encountering a threatening situation, whereas Moses's companions were worried saying We are overtaken by Pharaoh's soldiers, Moses -- secure in his knowledge of Allah's responsiveness -- addressed his companions' worry, stating: "No! My Lord is with me, He will guide me." This and other similarly themed Quranic stories speak of the availability of Allah to His servants, and demonstrate how during times of distress and threat believers engage in seeking proximity (activation of attachment). They find refuge in Allah (safe haven) and courage and conviction to take a firm stance in the knowledge of Allah's ongoing responsiveness and preparedness to protect, shield, and guide his Prophets and people.

Whereas many stories point to the possibility of secure attachment to Allah, others depict followers of Allah who demonstrate a lack of faith in Allah's protection and guidance and hence do not find a safe haven and secure base in Allah. For example, the story of Moses also shows his people distressed under Pharaoh and yet hesitant to resist Pharaoh's oppression (Qur'an 26: 10-69; 28: 3-5). They seemed to lack a sense of secure spiritual base that would allow them to venture into an unknown future. Another example is some of the companions of the Prophet who were anxious about being captured by enemies while they were in the cave. Yet the Prophet assured them of being saved by Allah since Allah was very close to them (9:40). Their anxiety is consistent with insecure attachment because they did not seek Allah as their haven of safety and did not consider Allah as their secure base. 
While the above is only a brief overview, these and other stories from the Quran are full of characters that experienced Allah as their attachment figure at crucial and decisive moments of in their lives. Most are examples of secure attachment, but there are also references to insecure styles of attachment. By extension, these stories speak to today's Muslim believers reminding them that they too can seek protection and security from God. The examples of insecure attachment are warnings that encourage believers to overcome any ambivalence or avoidance in their relationship with Allah.

\section{Allah as Attachment Figure According to Qur'anic Verses}

Further evidence that Allah is an attachment figure can be found in Quranic verses that directly speak of attributes of Allah consistent with the defining qualities of an attachment figure. For example, some verses describe Allah as close and nurturing - a present, compassionate, and merciful figure who is able to provide protection.

One of the divine characters attributed to Allah is His omnipresence. Revelation indicates that "To Allah belongs the east and the west, wherever you go, there will be the presence of Allah. Allah is Omnipresent, Omniscient (Qur'an 2: 115). Believing that Allah is Omnipresent assures individuals of His availability without limiting Him in "space" or "time" boundaries. The closeness of Allah is further revealed in the Qur'an:

He is with us whenever we are (57:4);

$\mathrm{He}$ is also closer to us than our jugular vein (50:16);

He is closer to us than we all are, yet we all do not see (.56:85)

Wherever you turn, there is the face of Allah (2:115).

Ibn Arabi in reflecting on the verse "And He is with you wherever you are" (Qur'an 57:4) says Allah's love for human beings means that He never lets them out of His sight. In this and the prior verses the extent to which Allah is available, present and accessible to believers is evident. These references lend substantial support to the proposition that Allah is always present and can be called upon in times of threat. Confidence that Allah will respond is found in Allah's message in the Qur'an: "When My servants ask you about Me, I am always near. I respond to their prayers when they pray for $M e$ " (2: 186). Individuals such as Moses who have entered into a close and intimate relationship with Allah are not afraid of threatening situations and can inspire others who do feel threatened to seek Allah's protection and care. Moses' confidence in Allah's protection is grounded in his knowledge that "My Lord is with me; soon He will guide me" (Qur'an 26: 62). 
As a complement to verses that depict Allah as a fully nurturing attachment figure are others that proclaim Allah's justice and hatred of sinfulness. For example, Allah is depicted as an avenger of evil (Qur'an 3:4; 5:95; 14:47; 39:37) and as punishing wrongdoing $(2: 165 ; 6: 147-148 ; 7: 4-5 ; 7: 97)$. Such verses raise the possibility of insecure attachment among believers whose dominant experience of Allah is one of punishment.

While by no means a comprehensive list of Qur'anic verses that provide evidence of Allah functioning as an attachment figure, this small selection when added to Quranic stories and the Divine names of Allah outlined above, clearly suggests believers will be well-received when they turn to Allah during their times of need. Further, they suggest that Allah as the 'stronger, wiser other' provides a 'secure base' from which to explore and mature as a Muslim believer. They also raise the possibility of insecure attachment when believers primarily experience more negative themes in their relationship with Allah.

\section{Attachment Behaviors of Believers}

Although behaviors in themselves cannot confirm an attachment relationship, some behaviors are suggestive of an attachment bond. Within Christian contexts raising hands to God, crying out to God in supplicatory prayer, and church attendance are proposed as examples of Christians engaging in attachment behaviors (Kirkpatrick 1992a). These behaviors may indicate proximityseeking or a referencing back to Allah as a secure base. Further, in separation protest, wherein Christians experience a sense that they have been abandoned by God and lament their 'dark night of the soul' can also indicate attachment (Beck, 2006). Similar attachment behaviors can be discerned in Muslims' relating to Allah, as are discussed below.

\section{Proximity Seeking}

Seeking proximity to Allah is the ultimate goal of the rituals and practices of Muslim people. Reciting daily prayers, almsgiving, going on pilgrimage, and visiting sacred shrines are among rituals that are performed with the intent to obtain closeness to Allah. The core of individuals' worship and rituals is succinctly described in the following Quranic verse, which emphasizes the proximity-seeking function of ritual:

[O Prophet] Say: Surely my prayer, my devotions, my life, and my death are all for [the proximity of] Allah, the Lord of the world (6: 162). 
Attachment behaviors are activated in times of intense need and in the context of threatening events. An example of proximity-seeking can be seen in Chapter 3 of the Qur'an wherein the Prophet Mohammad and his followers, when confronted with threatening news, seek out Allah, and draw upon His blessings, which in turn enable them to confront the threat:

People have gathered against you, so fear them, [This] increased them in their faith and they said: "Allah is sufficient for us. How excellent a guardian $\mathrm{He}$ is. So they returned with blessing and bounty from Allah, no harm ever touched them (173-174).

In Allah was found all that is needed and sufficient for the Prophet and believers to traverse their dilemma.

\section{Proximity Seeking as Depicted in Supplications}

The Islamic heritage also includes famous supplications invoked by the Prophet Mohammad and his household demonstrating their deep personal relationship with Allah. The intimate and loving relationship that is portrayed in these supplications indicates Muslims' deep feelings about Allah, and their close personal connection with the divine being. Without considering these supplications it is hard to understand the emotional and mystical aspect of Islam. The relationship of humans with the divine while reading these supplications is similar to the relation of a distressed child calling his/her mother for help. Following are a few phrases selected from Kumayl's Invocation (which is valuable to Shia Muslims:

O’ Allah I ask you by your munificence that you bring me close to yourself. You are too generous to abandon one whom you have sustained, or keep away the one whom you have kept close to yourself, displace the one whom you have given shelter. My master, protector, and Lord, suppose that I can endure your hell fire (punishment because of my sins), how can I tolerate separation from you? (Qumi, 2005)

Another example of Muslim supplications that show individuals' deep attachment relation with Allah is Imam ${ }^{5}$ Zayn Al 'Abidin's supplications as follows:

5. Imam Zayn Al-Abedin (659-710) is a great-grand son of Muhammad as well as the fourth Shiah imam. His mother was Shahrbanu and his father was Hussayn ibn Ali. His brothers include Ali:Ali al Asghar, and Ali al Akbar. He is known as zayn al-Abdin the "beauty/best of worshipers". He also is known as "Imam al sajjad", the leader of individuals who prostrate to Allah. His beautiful prayers are compiled in the book titled "Al-Sahifat Al-Sajjadiyya". 
O' Allah I ask you by the splendors of Your face and light of your holiness, the tenderness of your mercy and gentleness of your goodness, to verify my opinion in expecting your great generosity and your beautiful favor, through nearness to you, proximity with you and enjoyment of gazing upon you. I have come to you craving your beneficence, desiring your kindness, requesting your good pleasure, wanting your face, knocking at your door, abasing myself before Your mightiness and majesty (Imam Zayn Al 'Abidin, 1988).

In supplications that are spontaneous utterances of the heart, inspired by Allah and uttered by a servant, intense dialogue between a human and the divine takes place. These supplications demonstrate the affective component of an attachment bond (Schore, 1994), both in regulating negative emotion (separation anxiety) and enhancing positive emotion (joy in the good).

\section{Facilitating Psychological Proximity through Remembrance}

Although Muslims believe that Allah is omnipresent, there are means available to facilitate an individual's access to Allah's proximity. When Muslims go to the mosque to pray and orient themselves toward Ka'ba or when they go to Mecca for the pilgrimage of Ka'ba, the sacred place Abraham made for the sake of Allah, they make the abstract relation with the divine more concrete and facilitate their conceptualization of divine proximity. Remembering Allah in one's heart and rehearsing His holy name verbally is a way of facilitating divine proximity and hence constitutes another attachment for Muslims. Maintaining a sense of closeness to Allah helps to equip Muslims with the courage and strength to engage and endure through the challenges of their lives. Through remembrance believers can feel endowed with care, love, and protection that can help them cope with life. Divine sayings such as those below (narrated by the Prophet) illustrate the power of remembrance and active imagination in Islamic tradition:

Allah, ever mighty and majestic is He says: I am with my servant whenever he remembers Me and when his lips move in mention of Me (Ibn Arabi, 2004, p.33).

Moreover, Allah states:

I am present in My servant's thought of Me, and I am with him when he remembers Me (Ibn Arabi, 2004, p.46).

As long as individuals' minds and hearts are full of Allah's remembrance Allah is with them, wherever they may be. The following saying indicates the importance of calling upon Allah to feel His presence: 
Allah, ever mighty and majestic is He says: "I am present in My servant's thought of Me, and I am with him when he beseeches Me" (Ibn Arabi, 2004, p.34).

In the context of an attachment bond, this presents Allah as the ideal attachment figure in His ever-present availability. Muslim believers can be confident that their proximity-seeking will yield a greater closeness to Allah. Indeed Allah makes clear that believers when faced with enemies can find Allah in their remembrance of Him:

My true servant is the one who is in remembrance of Me when he faces his enemy" (Ibn Arabi, 2004, p.60).

\section{Response to Separation and Loss}

As Ainsworth (1985b) reported, the threat of separation from an attachment figure causes anxiety in the attached person, and the loss of the attachment figure causes grief. Among believers, it is perceived abandonment by Allah that constitutes an acute form of separation anxiety, and results in separation protest.

Unlike human attachment figures, Allah as omnipresent is an ultimate figure of attachment in that He never leaves believers (Qur'an 57:4). However, some Islamic Mystics consider the Fall of Adam a major archetypal separation from the Divine and lament the loss, yearning for reunion (Rumi ${ }^{6}, 1978$ ). Such a nostalgic reaction to this spiritual collective loss is expressed by Persian Muslim mystics (see Sabzawari Khurasani, 2008). The following famous divine saying speaks of the depth of anxiety and fear of losing proximity to the divine attachment figure in Islamic spirituality, which exists not only in believers but also in prophets such as Abraham:

Allah, ever mighty and majestic is He, said to His prophet and intimate friend Abraham, upon him be peace: "What is this terrible fear you have?" Abraham replied: "O my Lord, how should I not suffer fear and dread when my father Adam, may Allah bless him and give him peace, was in closeness with You; You created him with Your own hand, and breathed into him of Your own spirit; You commanded the angels to prostrate themselves be-

6. Rumi, Jalal ad-Din Muhammad Balkhi (1207-1273) was a 13th century Persian poet, jurist, theologian, and mystic. He was born in Balkh, Khorasan. His birthplace and native language both indicate a Persian heritage. He died in 1273, and he was buried in Konya where his shrine became a place of pilgrimage. He is one of the famous Sufis in Persian, and his six volume Masnawi is a mystical interpretation of Qur'an. 
fore him; and yet, for a single act of disobedience, You cast him from Your proximity?" Then Allah inspired him thus: "O Abraham, do you not know how hard disobedience against the beloved is for the beloved?" (Ibn Arabi, 2004, p.57)

Just as the child unable to obtain proximity to its attachment figures cries out in distress, so too, believers lament when faced with separation from Allah, their ultimate attachment figure.

\section{Implications for Muslim Mental Health}

As indicated in the previous sections attachment to parental figures or primary caregivers has implications for an individual's mental health in adulthood. Research shows that insecure attachment in individuals is associated with anxiety disorders (Fonagy et al., 1996), panic disorders (Brown \& Harris, 1993), depression (Cole-Detke \& Kobak, 1996; Rosenstein \& Herowitz, 1996), dissociative symptoms (Liotti, 2004), eating disorders (Cole-Detke \& Kobak, 1996), borderline personality disorders (Fonagy et al., 1996), antisocial personality disorders (Babcock, Jacobson, Gottman, \& Yerington, 2000), and schizophrenic tendencies (Zanarini et al., 1989). Insecure attachment to God is also associated with poor mental and physical health (Dozier, Stovall-McClough, \& Albus, 2008; Crowell, Fraley, \& Shaver, 1999), inadequate and ineffective coping (Belavich \& Pargament, 2002), neuroticism (Beck \& McDonald, 2004), and loneliness (Kirkpatrick, Shillito, \& Kellas, 1998). On the other hand, a secure attachment to God is associated with a wide variety of better health outcomes (Dozier, Stovall-McClough, \& Albus, 2008), including a reduced sense of loneliness (Kirkpatrick, Shillito, \& Kellas, 1998), superior relationship functioning (Hesse, 1999), a choice of effective coping strategies (Belavich \& Pargament, 2002), lower depression, anxiety, and physical illness, and substantially higher general life satisfaction (Kirkpatrick \& Shaver, 1992).

Just as providing psychological care to Christians requires consideration of an individual Christian's relationship with and attachment to God, so too a Muslim's relationship with and attachment to Allah requires consideration when addressing their psychological care. Instances have been given above of relational qualities consistent with both apparently secure and insecure attachment among Muslims. However, assessing Muslims' attachment to Allah is presently constrained by the current absence of appropriate tools specifically designed to tap into Muslim experiences of attachment to Allah. Rightfully, most Muslim psychologists do not include instruments designed for use with Christians in their research or clinical work with Muslim populations because of fundamental theological differences between Christianity and Islam. This 
lack of suitable assessment tools creates problems in delivering comprehensive and targeted psycho-spiritual interventions that address the needs of Muslim clients and in estimating intervention effectiveness (Richards \& Bergins, 1997). Particularly of concern is how to address psychological problems that originate from (or have a connection with) the state of a Muslim's attachment to Allah (Granqvist \& Kirkpatrick, 2008) in the absence of an appropriate assessment tool for assessing Muslim attachment to Allah. Psychologists working with Muslim clients may be unaware as to whether a client's presenting psychiatric problem is linked to his/her spirituality, and more specifically, the individual's attachment to Allah.

In an attempt to equip psychologists working with Muslim clients to be able to assess and include attachment to Allah among their repertoire of assessment tools, the current authors are developing a scale to measure Muslims' attachment to the divine being. If the scale is to be useful in practice it must be able to distinguish attachment security from insecurity, and, ideally, distinguish different styles within overall attachment insecurity, such as ambivalent/ preoccupied; avoidant/dismissing; and fearful/disorganized.

As part of the process, prior to development of the scale, a theological and theoretical analysis of Muslims' understanding and experience of being attached to Allah is required. Only after examining the attachment to Allah construct within the context of Islamic spirituality would it be possible to ensure that the scale itself was appropriately grounded in Islamic spirituality. The current paper has reported the findings of this theological and theoretical investigation. Therefore, psychologists interested in using the construct of attachment to Allah will appreciate its grounding in Muslims' experiences of being in a relationship with Allah. This knowledge coupled with the forthcoming scale will enable them to assess and support Muslim clients in resolving and/or managing psychological and psychiatric issues, especially those relating to the state of their attachment to Allah.

\section{Conclusion}

An important focus within the psychology of religion over the last two decades has been exploring the nature and consequences of attachment to Allah. Most of the theorizing and research related to attachment to God has been based on Christian theology and accounts of Christian beliefs, experiences and practices. However, the utility of the construct is by no means limited to explaining aspects of the Christian experience and, as the current paper has shown, Muslims also can form an attachment to Allah according to their sacred texts. This paper presents a theological analysis of Muslim writings in order to assess the validity of the construct for Muslims. From an analysis of the divine names, stories from the Qur'an, and direct revelation (verses) in the Qur'an it can be 
concluded that Allah is depicted as having key attributes of an attachment figure: namely, one who is close, responsive, and compassionate; and one who provides security and protection in times of danger. Thus, Allah fulfills critical attachment functions of proximity, safe haven, and secure base. Similarly, Muslim believers are depicted as seeking proximity to and a safe haven in Allah and protesting separation from Allah, all functions of a secure attachment bond. Conversely, other believers are depicted as avoiding proximity to Allah and failing at times to use Allah as a safe haven and secure base. These styles of relating to Allah are consistent with an insecure attachment bond. Hence, there are sound theoretical reasons for hypothesizing that part of a Muslim's relationship with Allah can be regarded as being that of an attachment bond.

The present paper has only presented the theological grounds for depicting attachment as a component of a believer's relationship with Allah. The authors recognize that empirical studies of attachment to Allah are warranted. To that end they are currently developing a Muslim attachment to Allah scale and are engaged in validating the new scale among a Muslim sample. More broadly, future work is needed that examines individual differences in attachment to Allah and investigates the relationship between Muslims' attachment to Allah and their psychological health and well-being. Indicators of psychological health would include low levels of symptoms of Axis I and II disorders, and measures of positive well-being would include higher levels of adaptive attributes (such as resilience, altruism, tolerance) and overall life satisfaction. In future studies, it would also be important to examine how Muslim ATG relates a) to other religious constructs such as intrinsic commitment, adherence to orthodox beliefs, involvement in religious community, religious coping, etc.; and b) to other attachment relationships with parents, romantic partners and close friends. It is likely that similar results would be found for Muslims compared to earlier studies on Christians, but predictions must be based on systematic theological and theoretical comparisons.

Some implications of Muslim attachment to Allah for psychological health have been outlined in the current paper, but require further clinical investigation. Differences between those who hold to Sunni, Shia, or Sufi perspectives would also be worthy of investigation. Nonetheless, we assert there are sound theoretical and theological reasons for pursuing studies of attachment to Allah among Muslims.

\section{References}

Ainsworth, M. D. S. (1985a). Attachments across the life span. Bulletin of the New York Academy of Medicine, 61, 792-812.

Ainsworth, M. D. S. (1985b). Patterns of infant-mother attachments: Antecedents and effects on development. Bulletin of the New York Academy of Medicine, 61, 771791. 
Ainsworth, M. D. S., Blehar, M. C., Waters, E., \& Wall, S. (1978). Patterns of attachment: A psychological study of the strange situation. Hillsdale, NJ: Lawrence Erlbaum Associates.

Al-Bukhari, M. (1979). The Translation of the meanings of Sahih al-Bukhari (trans. by Muhammed Muhsin Khan). Chicago: Dar-us-Salam Publications.

Al-Ghazzali, I. M. (1992). The ninety-nine beautiful names of God: Al-Maqsad al-asna fi sharh asma Allah al-husna (translated with notes by David, B. Burrell and Nazih Daher). Cambridge, UK: Islamic Texts Society.

Allen, J. P., Marsh, P., McFarland, C. McElhaney, K. B., Land, D. J., \& Jodl, K. M. (2002). Attachment and autonomy as predictors of the development of social skills and delinquency during midadolescence. Journal of Consulting and Clinical Psychology, 70, 56-66. http://dx.doi.org/10.1037/0022-006X.70.1.56

Arberry, A. J. (1962). The Qur'an interpreted. London: Touchstone.

Babcock, J. C., Jacobson, N. S., Gottman, J. M., \& Yerington, T. P. (2000). Attachment, emotional regulation, and the function of marital violence: Differences between secure, preoccupied, and dismissing violent and nonviolent husbands. Journal of Family Violence, 15, 391-409. http://dx.doi.org/10.1023/A:1007558330501

Bartholomew, K., \& Horowitz, L. M. (1991). Attachment styles among young adults: A test of a four-category model. Journal of Personality and Social Psychology, 61, 226-244. http://dx.doi.org/10.1037/0022-3514.61.2.226

Beck, R. (2006). God as a secure base: Attachment to God and theological exploration. Journal of Psychology and Theology 34, 125-132.

Beck, R., \& McDonald, A. (2004). Attachment to God: The Attachment to God Inventory, tests of working model correspondence, and an exploration of faith group differences. Journal of Psychology and Theology, 32, 92-103.

Belavich, T. G., \& Pargament, K. I. (2002). The role of attachment in predicting spiritual coping with a loved one in surgery. Journal of Adult Development, 9, 13-29. http:// dx.doi.org/10.1023/A:1013873100466

Bowlby, J. (1969). Attachment. New York: Basic Books.

Bowlby, J. (1973). Susceptibility to fear and the availability of attachment figures. In Separation: Anxiety and Anger, edited by M. M. Khan. London: The Hogarth Press.

Bowlby, J. (1977). The making and breaking of affectional bonds: I. Aetiology and psychopathology in the light of attachment theory. British Journal of Psychiatry, 130, 201-210. http://dx.doi.org/10.1192/bjp.130.3.201

Bowlby, J. (1982). Attachment. New York: Basic Books.

Bowlby, J. (1980). Loss: Sadness and Depression. London: Plimico.

Bowlby, J. (1982). Attachment and loss: Retrospect and prospect. American Journal of Orthopsychiatry, 52, 664-678. http://dx.doi.org/10.1111/j.1939-0025.1982. tb01456.x

Bowlby, J. (1987). Defensive processes in the light of attachment theory. In D. P. Schwartz, J. L. Sacksteder \& Y. Akabane (Eds.), Attachment and the therapeutic process: Essays in honor of Otto Allen Will, Jr. (pp. 63-79). Madison, CT: International Universities Press.

Bowlby, J. (1988a). Defensive processes in response to stressful separation in early life. In E. J. Anthony and C. Chiland (Eds.), The child in his family, Vol. 8: Perilous development: Child raising and identity formation under stress. New York: John Wiley.

Bowlby, J. (1988b). Developmental psychiatry comes of age. American Journal of Psychiatry, 145, 1-10.

Bowlby, J. (1988c). A secure base: Clinical applications of attachment theory. London: Tavistock-Routledge. 
Brown, G. W., \& Harris, T. O. (1993). Aetiology of anxiety and depressive disorders in an inner-city population: 1. Early adversity. Psychological Medicine, 23, 143-154. http://dx.doi.org/10.1017/S0033291700038939

Cassidy. J. (1994). Emotion regulation: Influences of attachment relationships. Monographs of the society for research in child development, 59, 228-249. http://dx.doi. org/10.2307/1166148

Cassidy, J. (1995). Attachment and generalized anxiety disorder. In D. Cicchetti \& S. Toth (Eds.), Rochester Symposium on Developmental Psychopathology, Vol. 6: Emotion, cognition, and representation (pp. 343-370). Rochester, NY: University of Rochester Press.

Cassidy, J. (1999). The nature of the child's ties. In J. Cassidy \& P. R. Shaver (Eds.), Handbook of attachment: Theory, research, and clinical applications. New York, NY: Guilford Press.

Chittick, W. C. (1989). The Sufi path of knowledge: Ibn al-Arabi's metaphysics of imagination. Albany, NY: SUNY Press.

Chittick, W. C. (1998). The self-disclosure of God: Principles of Ibn al-Arabi's cosmology. Albany, NY: SUNY Press.

Cole-Detke, H., \& Kobak, R. (1996). Attachment processes in eating disorder and depression. Journal of Counsulting and Clinical Psychology, 64, 282-290. http://dx.doi. org/10.1037/0022-006X.64.2.282

Crowell, J. A., Fraley, R. C., \& Shaver, P. R. (1999). Measurement of individual differences in adolescent and adult attachment. In J. Cassidy \& P. R. Shaver (Eds.), Handbook of attachment: Theory, research, and clinical applications (pp. 434-465). New York: Guilford Press.

Dover, H., Miner, M. \& Dowson, M. (2007). The nature and structure of Muslimreligious reflection. Journal of Muslim Mental Health, 2, 189-210. http://dx.doi. org/10.1080/15564900701614858

Doyle, A. B., \& Markiewicz, D. (2005). Parenting, marital conflict, and adjustment from early- to mid-adolescence: Mediated by adolescent attachment style? Journal of Youth and Adolescence, 34, 97-110. http://dx.doi.org/10.1007/s10964-005-3209-7

Dozier, M., Stovall-McClough, K. C., \& Albus, K. E. (2008). Attachment and psychopathology in adulthood. In J. Cassidy \& P. R. Shaver (Eds.), Handbook of attachment: Theory, research, and clinical applications. (pp. 718-744). New York: Guilford Press.

Dwairy, M. (2006). Counseling and psychotherapy with Arabs and Muslims: A culturally sensitive approach. New York: Teachers College Press.

Feeney, B. C. (2007). The dependency paradox in close relationships: Accepting dependence promotes independence. Journal of Personality and Social Psychology, 92, 268-285. http://dx.doi.org/10.1037/0022-3514.92.2.268

Fonagy, P., Leigh, T., Steele, M., Steele, H., Kennedy, R., Mattoon, G., et al. (1996). The relation of attachment status, psychiatric classification, and response to psychotherapy. Journal of Consulting and Clinical Psychology, 64, 22-31. http://dx.doi. org/10.1037/0022-006X.64.1.22

Francis, L. J., \& Stubbs, M. T. (1987). Measuring attitudes towards Christianity: From childhood to adulthood. Personality and Individual Differences, 8, 741-743. http:// dx.doi.org/10.1016/0191-8869(87)90075-4

Galanter, M., Rabkin, R., Rabkin, J. G., \& Deutsch, A. (1979). The "Moonies”: A psychological study of conversion and membership in a contemporary religious sect. American Journal of Psychiatry, 136, 165-170.

Glaser, I. (1986). The concept of relationship as a key to the comparative understanding of Christianity and Islam. Themelios, 11(2), 57-60. 
Glock, C. Y. \& Stark, R. (1965). Religion and society in tension. Chicago: Rand McNally. Granqvist, P., \& Kirkpatrick, L. A. (2008). Attachment and religious representation and behavior. In J. Cassidy \& P. R. Shaver (Eds.), Handbook of attachment: Theory, research, and clinical applications (pp. 906-933). New York: Guilford Press.

Haque, A. \& Mohamed, Y. (Eds.). (2009). Psychology of Personality: Islamic Perspectives. Singapore: Cengage Learning.

Hazan, C. \& Shaver, P. R. (1994). Attachment as an organizational framework for research on close relationships. Psychological Inquiry, 5,1-22. http://dx.doi. org/10.1207/s15327965pli0501_1

Hazan, C. \& Zeifman, D. (1994). Sex and psychological tether. In K. Bartholomew \& D. Perlman (Eds.), Advances in personal relationships (vol. 5; pp.151-180). London: Jessica Kingsley.

Hesse, E. (1999). The adult attachment interview: Historical and current perspectives. In J. Cassidy \& P. R. Shaver (Eds.), Handbook of attachment: Theory, research, and clinical applications (pp. 395-433). New York: Guilford Press.

Hill, P. C. (2005). Measurement in the psychology of religion and spirituality: Current status and evaluation. In R. F. Paloutzian \& C. L. Park (Eds.), Handbook of the psychology of religion and spirituality (pp. 43-61). New York: Guilford.

Hood, R. W., Jr., Spilka, B., Hunsberger, B., \& Gorsuch. R. (1996). The psychology of religion: An empirical approach ( $2^{\text {nd }}$ ed.). New York: Guilford press.

Hull, J. G., Young, R. D., \& Jouriles, E. (1986). Applications of the self-awareness model of alcohol consumption: Predicting patterns of use and abuse. Journal of Personality and Social Psychology, 51, 790-796. http://dx.doi.org/10.1037/0022-3514.51.4.790

Ibn Arabi, M. (1392/1972). Futuhat al-Makkiyya (ed. O. Yahya). Cairo, Bibliotheca Arabica.

Ibn Arabi, M. (1980). The Bezels of Wisdom (trans. R. W. J. Austin). Ramsey, NJ, Paulist Press.

Ibn Arabi, M. (1999). Kashf al-Ma'na an sirr asma Allah al-husna, Qum: Bakhshayish.

Ibn Arabi, M. (2004). Divine sayings: Mishkat al-anwar, (trans. into English with Arabic text by Stephen Hirtenstein, \& Martin Notcutt), Oxford: Anqa Publishing.

Ibn-Kathir, I. (2003). Stories of the prophets (trans. Rashad Ahmad Azami). Riyadh, Saudi Arabia: Darussalam.

Imam Zayn Al-Abidin (d.710). Psalms of Islam: Al-Sahifat Al-Sajjadiyya (translated by William C. Chittick, 1988). Oxford: Oxford University Press.

Jaffari-Bimmel, N., Juffer, F., van IJzendoorn , M. H., Bakermans-Kranenburg, M. J., \& Mooijaart, A. (2006). Social development from infancy to adolescence: Longitudinal and concurrent factors in an adoption sample. Developmental Psychology, 42, 1143-1153. http://dx.doi.org/10.1037/0012-1649.42.6.1143

Jones, A. (2007). The Quran: Translated into English. Oxford: Gibb Memorial Trust.

Khodayarifard, M., Ghobari Bonab, B., Shokoohi Yekta, M., Behpajoh, A., Afrooz, G. A., Abedini, Y. \& Parknejadi, M. (2008). Developing a religiosity scale for Iranian college students. Journal of Psychology and Education, University of Tehran, 38(3), 23-115.

Kirkpatrick, L. A. (1992a). An attachment-theoretical approach to the psychology of religion. International Journal for the Psychology of Religion, 2, 3-28. http://dx.doi. org/10.1207/s15327582ijpr0201_2

Kirkpatrick, L. A., \& Shaver, P.R. (1992b). An attachment-theoretical approach to romantic love and religious belief. Personality \& Social Psychology Bulletin, 18, 266275. http://dx.doi.org/10.1177/0146167292183002

Kirkpatrick, L. A. (1997). A longitudinal study of changes in religious belief and behav- 
ior as a function of individual differences in adult attachment style. Journal for the Scientific Study of Religion, 36, 207-217. http://dx.doi.org/10.2307/1387553

Kirkpatrick, L. A. (1998). God as a substitute attachment figure: A longitudinal study of adult attachment style and religious change in college students. Personality \& Social Psychology Bulletin, 24, 961-973. http://dx.doi.org/10.1177/0146167298249004

Kirkpatrick, L. A. (1999). Attachment and religious representations and behavior. In J. Cassidy \& P. R. Shaver (Eds.), Handbook of attachment: Theory, research, and clinical applications (pp. 803-822). New York: Guilford.

Kirkpatrick, L. A. (2005). Attachment, evolution, and the psychology of religion. New York: Guilford.

Kirkpatrick, L. A., \& Shaver, P. R. (1990). Attachment theory and religion: Childhood attachments, religious beliefs, and conversion. Journal for the Scientific Study of Religion, 29, 315-334. http://dx.doi.org/10.2307/1386461

Kirkpatrick, L. A., Shillito, D. J., \& Kellas, S. L. (1999). Loneliness, social support, and perceived relationships with God. Journal of Social and Personal Relationships, 16, 513-522. http://dx.doi.org/10.1177/0265407599164006

Kobeisy, A. N. (2006). Faith-based practice: An introduction. Journal of Muslim Mental Health, 1, 57-63. http://dx.doi.org/10.1080/15564900600697749

Liotti, G. (2004). Trauma, dissociation, and disorganized attachment: Three strands of a single braid. Psychotherapy, 41, 472-486. http://dx.doi.org/10.1037/00333204.41.4.472

Mikulincer, M., Gillath, O., \& Shaver, P. R. (2002). Activation of the attachment system in adulthood: Threat-related primes increase the accessibility of mental representations of attachment figures. Journal of Personality and Social Psychology, 83, 881895. http://dx.doi.org/10.1037/0022-3514.83.4.881

Miller, W. R., \& Thoresen, C. E. (1999). Spirituality and health. In W. R. Miller (Ed.), Integrating spirituality into treatment: Resources for practitioners (pp. 3-18). Washington, DC: American Psychological Association. http://dx.doi.org/10.1037/10327-001

Miner, M. H. (2007). Back to the basics in attachment to God: Revisiting theory in light of theology. Journal of Psychology and Theology, 35, 112-122.

Miner, M. (2009). The impact of child-parent attachment, attachment to God and religious orientation on psychological adjustment. Journal of Psychology and Theology, 37, 114-124.

Mohamed, Y. (1998) Human nature in Islam. Kuala Lumpur: Noordeen.

Nasr, S. H. (1997). Islamic spirituality: Foundations. New York: Crossroad Publishing Company.

Pargament, K. (1997). The psychology of religion and coping. New York: Guilford Press.

Pollner, M. (1989). Divine relations, social relations, and well-being. Journal of Health and Social Behavior, 30, 92-104. http://dx.doi.org/10.2307/2136915

Poloma, M. M., \& Gallup, G. H., Jr. (1991). Varieties of prayer: A survery report. Philadelphia: Trinity Press International.

Pouryousefi, H. (1984). Muslim religiosity and delinquency: An examination of Iranian youth. PhD dissertation, University of Essex.

Proctor, M. T. (2006). The God Attachment Interview Schedule: Implicit and explicit assessment of attachment to God., Unpublished dDoctoral dDissertation, School of Psychology, University of Western Sydney, Australia.

Proctor, M. T., Miner, M., \& Dowson, M. (in press). Assessing relationships between attachment to God, spiritual maturity and psychological health, Submitted to Review of Religious Research. 
Qumi, A. (2005). Mafatih-al-Jinan (Key to the Garden of Paradise), Qum, Iran: Ansariyan Publications.

Richards, P. S., \& Bergin, A. E. (1997). A spiritual strategy for counseling and psychotherapy, Washington, DC: American Psychological Association. http://dx.doi. org/10.1037/10241-000

Rowatt, W. C., \& Kirkpatrick, L. A. (2002). Two dimensions of attachment to God and their relation to affect, religiosity, and personality constructs. Journal for the Scientific Study of Religion, 41, 637-651. http://dx.doi.org/10.1111/1468-5906.00143

Rumi, J. M. (1978). The Mathnawi of Jalaluddin Rumi (trans. Reynold A. Nicholson). Cambridge, UK: E. J. W. Gibb Memorial.

Sable, P. (2000). Attachment and adult psychotherapy. Northvale, NJ: Rowman \& Littlefield..

Sabzawari Khurasani, S. M. A. (2008). Tuhfahyi-Abbasi: The Golden Chain of Sufism in Shi'ite Islam (trans. Mohammad H. Faghfoory). New York: University Press of America.

Samandari, J. M. (1982). The impact of religion, socio-economic status, and degree of religiosity on family planning among Moslems and Baha'is in Iran. PhD dissertation, University of North Colorado.

Schore, A. N. (1994). Affect regulation and the origin of the self: The neurobiology of emotional development. Hillsdale, NJ: Lawrence Erlbaum.

Schore, A. N. (2003). Affect dysregulation and disorders of the self. New York: Norton.

Serajzadeh, S. H. (1998). Muslim religiosity and delinquency: An examination of Iranian youth. $\mathrm{PhD}$ dissertation, University of Essex.

Sim, T. N., \& Loh, B. S. M. (2003). Attachment to God: Measurement and dynamics. Journal of Social and Personal Relationships, 20, 373-389. http://dx.doi. org/10.1177/0265407503020003006

Sroufe, L. A. \& Waters, E. (1977). Attachment as an organizational construct. Child Development, 48, 1184-1199. http://dx.doi.org/10.2307/1128475

Sroufe, L. A., Egeland, B., Carlson, E. A., \& Collins, W. A. (2005). The development of the person: The Minnesota study of risk and adaptation from birth to adulthood. New York: Guilford.

Sroufe, L. A., Egeland, B., \& Carlson, E. A.(1999). One social world: The integrated development of parent-child and peer relationships. In W. A. Collins \& B. Laursen (Eds.), Relationships as developmental contexts: The Minnesota Symposia on Child Psychology (pp. 238-259). Mahwah, NJ: Lawrence Erlbaum.

Ullman, C. (1982). Change of mind, change of heart: Some cognitive and emotional antecedents of religious conversion. Journal of Personality and Social Psychology, 42, 183-192. http://dx.doi.org/10.1037/0022-3514.43.1.183

Wilde, A. \& Joseph, S. (1997). Religiosity and personality in a Moslem context. Personality and Individual Differences, 23, 899-900. http://dx.doi.org/10.1016/S01918869(97)00098-6

Zanarini, M. C., Gunderson, J. G., Martino, M. F., Schwartz, E. O., \& Frankenburg, F. R. (1989). Childhood experiences of borderline patients. Comprehensive Psychiatry, 30, 18-25. http://dx.doi.org/10.1016/0010-440X(89)90114-4 